\title{
Riskli Sürücü Davranışlarının Transteorik Model Temelinde İncelenmesi: Bir Grup Karşılaştırması Çalışması
}

\author{
Bilgesu Kaçan ${ }^{1,2 *}$, U. Uygar Erkuş ${ }^{1}$, Gizem Fındık ${ }^{1}$, Bahar Öz ${ }^{1}$ \\ ${ }^{1}$ Güvenlik Araştırma Birimi, Psikoloji Bölümü, Orta Doğu Teknik Üniversitesi, Ankara Türkiye. \\ ${ }^{2}$ Psikoloji Bölümü, Necmettin Erbakan Üniversitesi, Konya Türkiye.
}

Öz

Dünya Sağlık Örgütü tarafından hız sınırını aşmak, alkol kullanmış olarak araç kullanmak, emniyet kemeri kullanmamak ve dikkati dağılmış olarak araç kullanmak riskli sürücü davranışları olarak belirtilmiş davranışlardır. Bu riskli davranışların Türk toplumunda hangi aşamada olunduğunun belirlenmesi ve değiştirilmesi trafik güvenliği açısından önem taşımaktadır. Mevcut çalışmada değişim için öngördüğü aşamalar ile yarar sağlayabileceği düşünülen Transteorik Model kullanılarak, bu riskli davranışlar için katılımcıların bulundukları basamakların tanımlanması ve olası farkların incelenmesi amaçlanmıştır. Anket yöntemi ile veri toplanan çalışmaya henüz sürücü olmayan ama gelecekte sürücü olma olasılığı bulunan 120 geleceğin sürücüsü, güvenli sürüş eğitimi almış 99 sürücü ve güvenli sürüş eğitimi almamış 140 sürücü katılmıştır. Beyana dayalı sonuçlar genel olarak değerlendirildiğinde, güvenli sürüş eğitimi almamış sürücü grubunun hız sınırları dâhilinde araç kullanma, alkollüyken araç kullanma, sürüş esnasında cep telefonu kullanma ve sürüş esnasında yemek yemek davranışlarında sürücü olmayan gruptan ve güvenli sürüş eğitimi almış gruptan anlamlı derecede daha alt basamaklarda oldukları bulunmuştur. Emniyet kemeri kullanımında ise sadece eğitim almamış sürücü grubunun sürücü olmayan gruptan anlamlı ölçüde daha alt basamaklarda oldukları görülmektedir. Güvenli sürüş eğitimi almış sürücüler ile henüz sürücü olmayan grubun farklılaştığı tek davranış ise sürüş esnasında cep telefonu kullanımı olmuş; henüz sürücü olmayan grubun eğitim almış sürücülerden daha üst basamaklarda olduğu bulunmuştur. Çalışmanın 359 katılımcısı göz önünde bulundurulduğunda bu beş riskli davranış için Transteorik Model'e göre harekete geçme basamağında yoğunlaştıkları bulgular arasındadır. Mevcut çalışma ile, güvenli trafik için gerekli olan beş davranış üzerinden çoğunlukla bulunulan basamağı tanımlayarak Transteorik Model'in basamaklarına göre geleceğe yönelik spesifik önleme ve müdahale programları geliştirebilecek çalışmalara zemin hazırlaması hedeflenmiştir.

Anahtar Kelimeler: transteorik model, değişim aşamaları, riskli sürücü davranışları, güvenli sürüş eğitimi

\section{Investigating Risky Driver Behaviours Based on the Transtheoretical Model: Comparison of Different Groups}

\begin{abstract}
Exceeding speed limits, driving under the influence of alcohol, not using seat belt, and distracted driving are accepted as risky driver behaviors by the World Health Organization. Determining the levels of risky behaviors in Turkish society and changing those behaviors are important to improve traffic safety in Turkey. The Transtheoretical Model, indicating the prescribed steps for change, was used to identify the steps for these risky behaviors and to examine possible differences. Data was collected via questionnaires from 120 drivers who do not hold driver licenses but are likely to be drivers in the future, 99 drivers with safe driving training and 140 drivers who have not received safe driving training. When the results of self-reports were evaluated in sum, it was found that the driver group who do not have safe driving training were significantly lower than non-driver group and the driver group who have safe driving training with regard to driving within the limits of speed, driving with alcohol, using mobile phone while driving and eating while driving. When the use of seat belts is considered, the driver group that does not have safe driving training is significantly lower than the non-driver group. Considering 359 participants of the study, the findings were revealed that the five risky behaviors were concentrated around the action step of the Transtheoretical Model. With the present study, it was aimed to prepare a working ground that could develop specific prevention and intervention programs in the future by identifying the steps regarding the five behaviors required for safe traffic in accordance with the steps of the Transtheoretical Model.
\end{abstract}

Keywords: transtheoretical model, stages of change, risky driver behaviors, safe driving training

\footnotetext{
* Illetişim / Contact: Bilgesu Kaçan, Güvenlik Araştırma Birimi, Psikoloji Bölümü, Orta Doğu Teknik Üniversitesi, Ankara Türkiye. E-posta / Email: kacanbilgesu@gmail.com Gönderildiği tarihi / Date submitted: 19.07.2018, Kabul edildiği tarih / Date accepted: 29.09.2018

Alıntı / Citation: Kaçan, B., Erkuş, U. U., Fındık, G. ve Öz, B. (2018). Riskli Sürücü Davranışlarının Transteorik Model Temelinde İncelenmesi: Bir Grup Karşılaştırması Çalışması. Trafik ve Ulaşım Araştırmaları Dergisi, 1(2), 33-47.
}

\section{TQ}




\section{Riskli Sürücü Davranışlarının Transteorik Model Temelinde İncelenmesi: Bir Grup Karşılaştırması Çalışması}

\section{Giriş}

Karayolunda meydana gelen trafik kazaları ölümle sonuçlanan kazaların başında gelmektedir. Dünya Sağlık Örgütü'nün (DSÖ) (World Health Organization [WHO], 2015) raporuna göre her yıl 1,2 milyondan fazla kişi trafik kazalarında hayatını kaybetmektedir ve trafik kazaları tüm yaş grupları göz önünde bulundurulduğunda ölüm nedenleri arasında 9. sırada yer almaktadır. Ayrıca DSÖ’nün tahminlerine göre 2020 yılında 1.9 milyon kişi trafik kazalarında hayatını kaybedecek, 20 ile 50 milyon arası kişi kazalarda yaralanacak ve trafik kazaları ölüm nedenleri arasında 5. siraya ulaşacaktır (WHO, 2013). Kaza ve ölümlü kaza oranlarına bakıldığında, trafik kazalarının küresel bir problem olmakla birlikte düşük ve orta gelirli ülkelerde daha da fazla olduğu yani daha büyük bir problem olduğu bilinmektedir (WHO, 2015). Orta gelirli ülkelerden biri olan Türkiye'deki trafik kaza raporları da bu oranı ortaya koymaktadır; 2016 yılında Türkiye'de 1 milyondan fazla kaza meydana geldiği ve bu kazaların 185 bininin ölümlü ya da yaralanmalı kaza oldukları raporlanmıştır (Türkiye İstatistik Kurumu [TÜIKK], 2017). Trafik kazalarının nedenleri üzerine yapılan çalışmalar trafik kazalarındaki sürücü hatalarının ve ihlallerinin etkilerini ortaya koymuştur. Kimi çalışmalar kazaların \%90'ının insan faktörü nedeniyle yani sürücüden dolayı olduğunu ortaya koyarken (Rumar, 1985), kimi çalışmalar da \%98'inin insan faktöründen kaynaklandığını ifade etmiştir (Nangana ve ark., 2016); Türkiye'de ise bu oranın \%89.6 olduğu ifade edilmiştir (TÜIKK, 2017). Oranlar çalışmadan çalışmaya farklılık gösterse de, kazaların oluşmasında insan faktörünün etkisinin yüksek olduğu çıkarımı yapılabilmektedir; bu nedenle sürücü davranışlarını incelemek ve güvenlik anlamında olumsuz olan davranışları oluştuğu koşullarda değerlendirip değiştirmek önem kazanmaktadır.

Dünya Sağlık Örgütü raporunda hız sınırını aşmak, alkollü ve uyuşturucu madde kullanmış olarak araç kullanmak, emniyet kemeri kullanmamak ve dikkati dağılmış olarak araç kullanmak riskli sürücü davranışları olarak belirtilmiş davranışlardır (WHO, 2015). Türkiye istatistiklerine bakıldığında araç hızını yol, hava ve trafiğin gerektirdiği şartlara uydurmamak kazaya neden olan sürücü faktörlerinde ilk sırada yer alırken alkollü araç kullanmak sekizinci sırada yer almaktadır; emniyet kemeri kullanmamak ise yolcu kusuru olarak geçmekte ve ikinci sırada yer almaktadır (Trafik Güvenliği Dairesi Başkanlığı, 2016).

Literatürde de yukarıda bahsi geçen davranışların trafik güvenliği için risk arz ettiği ortaya konulmaktadır. Alkollü araç kullanma ile kaza riski arasındaki ilişki incelendiğinde alkollü araç kullanma sonucu kaza riskinin \%11.4 ile \%51.9 arasında arttığı bulunmuştur (Zador, Krawchuk ve Voas, 2000). Alkollü araç kullanan sürücüler çoklu görevden ziyade tek bir görevi yerine getirme eğiliminde olduklarından dolayı (Parks ve ark., 2002) çoklu bir görev olan sürüş becerileri etkilenmekte ve normalde göze alacakları riskten daha fazlasını göze almaktadırlar (Laude ve Fillmore, 2015). Emniyet kemeri kullanımının güvenlik açısından önemli olduğunu ortaya koyan çalışmalar, emniyet kemerinin ölüm oranını \%41 oranında azalttığını (Evans, 1986), tek araçlı kazalarda bu oran \%62 iken iki araçlı kazalarda ise \%30 oranında azalttığını ortaya koymuşlardır (Evans ve Frick, 1986). Türkiye'de 2011, 2012 ve 2013 yıllarında meydana gelen ölümlü kazalara bakıldığında kaza anında sürücülerin \%27'sinin emniyet kemeri takmadığı görülmüştür (Demirkol, Tosun, ve Yüksel, 2015).Telefon kullanımının kazalardaki suç unsuru olması üzerine yapılan bir araştırmada araç kullanırken telefon kullanımının kaza oranını \%70 oranında arttırdığı bulunurken (Asbridge, Brubacher ve Chan, 2012), başka bir çalışmada bu oran \%73.2 olarak ifade edilmiştir (Bener, Crundall, Özkan ve Lajunen, 2010).

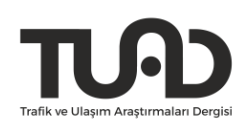


Araç kullanırken telefon kullandıklarını beyan eden sürücüler, telefon kullanımı esnasında kendi sürüşlerini değerlendirmiş ve o esnada daha dikkatsiz ve telaş içinde olduklarını kabul etmişlerdir (Beck, Yan ve Wang, 2007). Cep telefonu kullanmanın taktiksel aşama kararlarıyla ilişkili olduğu yani sürücünün sürüş becerisiyle ilgili kararlarındansa sürüş tarzı ile ilgili kararlarıyla bağlantılı olduğu da bulunmuştur (Bener, Lajunen, Özkan ve Haigney, 2006). Bunun yanında çalışmada dikkati dağılmış bir şekilde araç kullanımını ölçmek için kullanılan araç sürerken yemek yemenin kaza riskini arttırdığı (Young, Mahfoud, Walker, Jenkins ve Stanton, 2008); sürüş performansını olumsuz şekilde etkilediği, şerit pozisyon kontrolünü yapmayı zorlaştırdığı ve tepki süresini arttırdığı (Irwin, Monement ve Desbrow, 2015) bulunmuştur.

Sürücülerin yukarıda bahsi geçen riskli davranışlarını engellemek ve güvenli şekilde araç kullanmalarını sağlamak için kimi kurumlar "Güvenli Sürüş Eğitimi” vermektedir. Bu eğitimin içeriğinde pratik ve teorik defansif (güvenli) sürüş eğitimi, yorgunlukla mücadele eğitimi, gece sürüşü eğitimi, off-road (yol dişı/arazi) sürüş eğitimi gibi eğitimlere yer verilmektedir (bkz. Defansif sürüş eğitimi, 2018). Bahsi geçen eğitimler kapsamında sürücülerin saldırgan sürücü davranışlarından kaçınmalarının kendileri ve başkaları için kazanım olduğunu kavramaları hedeflenmektedir. Sürücülerin sadece sürüş becerilerini geliştirmeye yönelik uygulamaların değil aynı zamanda defansif sürüş yapmalarının önemine dair bilgilendirmelerin yapıldığı eğitimler 1 ile 3 yıl arasında tekrarlanmaktadır. Defansif sürüş eğitimlerinde öncelikli hedef yollardaki risklerin ve olası tehlikelerin sürücüler tarafindan anlaşılması ve eğitmenlerle birlikte değerlendirilmesidir. Bu eğitimlerin uygulama kısmında sürücüler eğitmenlerle birlikte gerçek trafik ortamında sürüş gerçekleştirirler ve böylece teorik kısımda edinilen bilgilerin uygulaması gerçekleştirilmiş olur. Yorgunlukla mücadele eğitiminde, sürücülerin sürüş sırasında oluşan yorgunluğu tanıyabilir hale gelmeleri, bunun sebeplerini ve sonuçlarını anlamaları, doğru analizleri yaparak karşılaşacakları sorunları çözebilir hale gelmeleri için bilgilendirme yapılır. Gece sürüşü eğitimlerinde, sürücülerin gece sürüşünde karşılaşılan insan, taşıt, hava ve yol koşullarından kaynaklanan riskleri anlamaları; ölü noktalar, farlar, görüş mesafesi ve netliği gibi konuları kavrayarak defansif sürüş gerçekleştirmeyi öğrenmeleri hedeflenmektedir. Son olarak, off-road sürüş eğitimlerinde sürücülerin karayolları dışında araç kullanmak durumunda kalmaları halinde dikkat etmeleri gereken hususlara ve geliştirmeleri gereken güvenli sürücü becerilerine odaklanılmaktadır. Özet olarak, sağlanan tüm bu eğitimlerde yol ve hava koşullarını tanıma, sürüş becerisini artırma, ortaya çıkan tehlike ve riskleri tespit etme ve sürüş sırasında meydana gelebilecek olumsuz durumlardan kaçınma ve bu tür durumlara sebebiyet vermeme gibi teorik ve pratik bilgilendirme uygulamaları yapılmaktadır. Manevra teknikleri, kayma kontrolü, frenleme gibi sürüşle ilgili yöntemsel beceri eğitimlerinin sürüş performansını artırdığı ortaya konmuştur (Isler, Starkey ve Sheppard, 2011). Defansif sürüş eğitimi öncesi ve sonrası ölçüm alınarak yapılan bir çalışmada, defansif sürüş eğitiminin sürücünün davranışlarını ya da kazaların nedenini neye atfettiğini değiştirdiği; nedeni içsel nedenlere atfetmesini arttırdığı ve bu değişimin de güvenli sürüşü yordadığı bulunmuştur (Huang ve Ford, 2012). Görülebileceği üzere trafik güvenliği açısından güvenli olmayan davranışları değiştirmek büyük önem taşımaktadır ve değişim sürecinde eğitimin etkilerini incelemek önemlidir.

Değişim dendiğinde akla gelen ilk modellerden biri Transteorik Model ya da diğer adıyla Değişim Basamakları Modelidir (Prochaska ve DiClemente, 1983). İlk olarak sigarayı bırakma davranışı üzerine geliştirilen bu modelin sonrasında birçok sağliklı davranışı edinme üzerine uygulandığı ve başarılı bulunduğu gözlemlenmiştir. Modele göre değişim, değişim hakkında düşünmemek ile yaptığı değişimleri sürdürmeye kadar giden bir süreci içermekte ve birbirini takip eden 5 basamak halinde gerçekleşmektedir (Prochaska, DiClemente ve

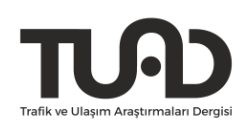


Norcross, 1992). Bu beş basamak sırasıyla ön-düşünme, düşünme, hazırlık, harekete geçme ve sürdürmedir (Prochaska ve DiClemente, 1983). Ön düşünme basamağında kişi sağlıksız davranışı hakkında hiçbir düşünceye sahip değildir ve davranışını sağlıksız olarak görmemektedir. Düşünme basamağında davranışının sağlıksızlığını ve değişmesi gerektiğini düşünmeye başlayan kişi, hazırlık aşamasında davranışını değiştirmek için stratejiler aramaya başlar. Harekete geçme aşamasında ise kişi değişim için adımlar atar, bilfiil değişim için uğraşmaktadır ve neredeyse değişimi başarmıştır. Sürdürme basamağında ise sağlıksız olan davranış sağlıklı davrnış ile değiştirilmiş ve sağlıklı davranış sürdürülmeye çalışılmaktadır. Değişimi sağlamak için her basamağa göre farklı müdahale programları önerilmektedir (DiClemente ve ark., 1991). Basamağa bağlı önerilen spesifik müdahale teknikleri Tablo 1'de gösterilmiştir.

Tablo 1. Değişim aşamalarına göre müdahale yöntemleri

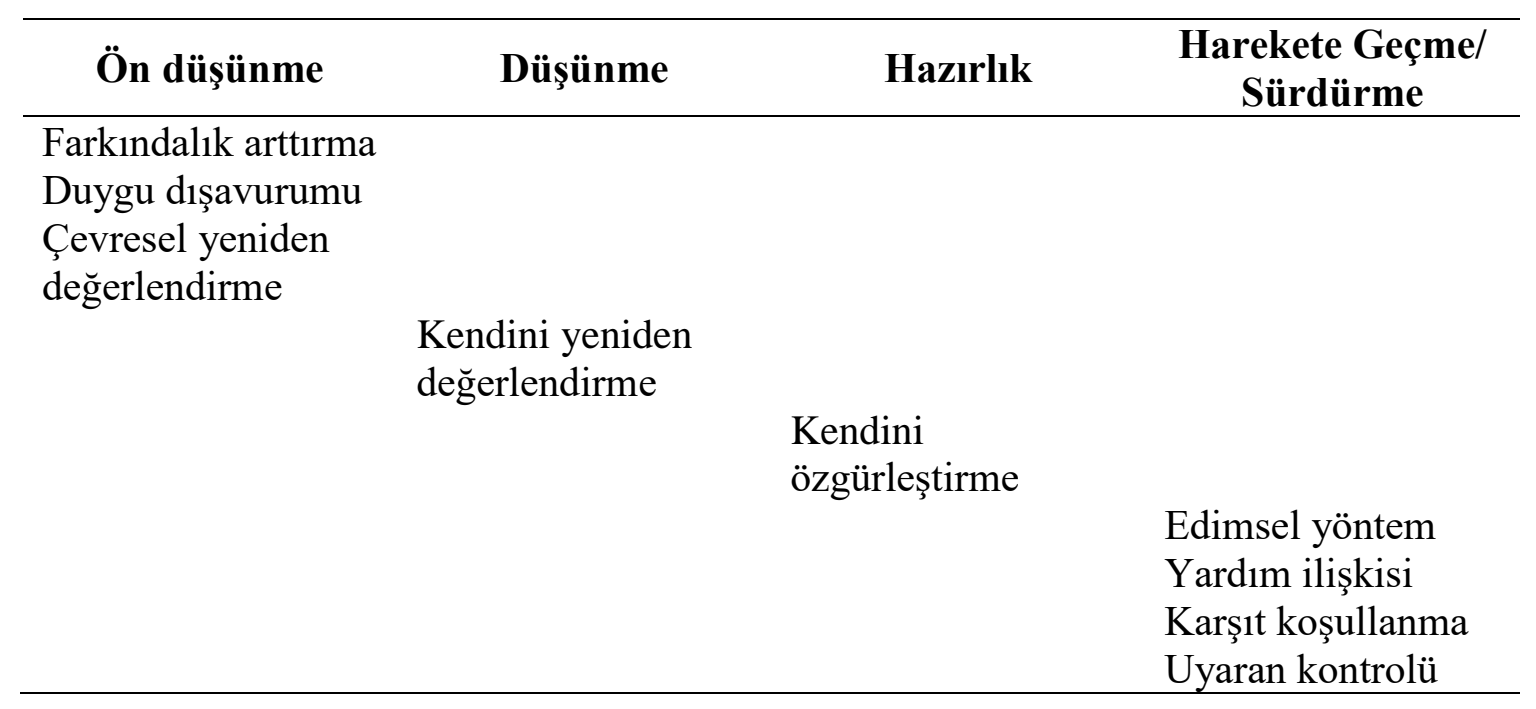

İnsanların hayatına mal olan trafik kazalarının ana nedeni olan riskli sürücü davranışları da sağlıksız davranışlar kategorisinde değerlendirilebilir. Bu davranışların Transteorik Model ile incelenmeye uygun olduğu da yapılan çalışmalar ile ortaya konulmuştur (Kowalski, Jeznach ve Tuokko, 2014; Tuokko, McGee ve Rhodes, 2006). Transteorik model sürücü davranışlarına uygulanır ve sürücülerin riskli davranışlar anlamında hangi basamakta olduğu bilinirse o basamağa yönelik müdahale de uygulanabilir (Asgarabad, Tahami ve Khanjani, 2012). İran'da yapılan bir çalışmada, Transteorik Modele göre dört yüksek riskli sürücü davranışı incelenmiş ve İranlı sürücülerin çoğunun bu riskli davranışlar arasında yer alan cep telefonu kullanımı ve emniyet kemeri kullanımında modelin ön düşünme basamağında olduğu bulunmuştur (Khadem-Rezaiyan, Moallem ve Vakili, 2017). Bir başka çalışmada da iş yerinde sürücü olarak çalışan kişilerin telefon kullanımı açısından hangi aşamada olduğu aynı model ile incelenmiş ve çalışanların ön düşünme basamağında olduğu bulunmuştur (Sinelnikov ve Wells, 2017). Bu çalışmalar göz önünde bulundurulduğunda sürüş esnasında cep telefonu kullanımının ve emniyet kemeri kullanmamanın sürücüler tarafından güvensiz/sağlıksız bir davranış olarak değerlendirilmediği çıkarımında bulunulabilir.

Trafik güvenliği açısından önemli olduğu düşünülen hız sınırları dâhilinde araç kullanma, alkollüyken araç kullanmama, emniyet kemeri kullanma, sürüş esnasında cep telefonu kullanmama, ve araç kullanırken yemek yememe davranışlarını incelemek ve olumsuz yönde olan davranışları olumlu yönde değiştirmek ve henüz sürücü olmayanlara yönelik olumlu davranışı kazandırıcı müdahaleler yapmak büyük önem taşımaktadır. Sürücülerin ve geleceğin sürücülerinin bulundukları aşamayı nasıl değerlendirdiklerinin aydınlatılması bu

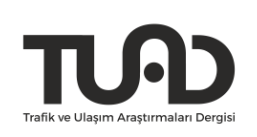


yolda atılan önemli bir adım olacaktır. Kişilerin bulundukları basamak anlaşıldıktan sonra basamağa ve gruba özgü spesifik önleme ve müdahale programları ilerideki çalışmalarda geliştirilebilecektir. Mevcut çalışma bu amaçları gerçekleştirmek için bir ön çalışma olup; çalışmada geleceğin sürücülerinin, güvenli sürüş eğitimi almış sürücülerin ve güvenli sürüş eğitimi almamış sürücülerin Transteorik Model'e göre bulundukları basamakları tanımlamak, grupların arasındaki farkı ortaya koymak hedeflenmektedir. Güvenli sürüş eğitimi almış sürücülerin diğer gruplara kıyasla daha üst basamaklarda olacağı beklenmektedir.

\section{Yöntem}

\section{1. Örneklem}

Çalışmanın örneklemi sosyal medya aracılığıyla ulaşılabilinen 359 kişiden oluşmaktadır. Katılımcılar çalışma anında sürücü olmayan 120 kişi (\%33.4), güvenli sürüş eğitimi alan 99 sürücü (\%27.6) ve güvenli sürüş eğitimi almamış 140 sürücüden (\%39) oluşmaktadır. Katılımcıların 194'ü erkek (\%54), 165'i kadın (\%46) olup, yaş aralığı 18-73 ve ortalaması 37.19'dur ( $S S=13.80)$. 5 kat1lımc1 ilkokul mezunu (\%1.4), 68 kat1lımc1 lise mezunu (\%18.9), 22 katılımcı ön lisans mezunu (\%6.1), 185 katılımcı üniversite mezunu (\%51.5), 63 katılımc1 yüksek lisans mezunu (\%17.5) ve 16 katılımc1 doktora mezunu (\%4.5) olduğunu beyan etmiştir.

\subsection{Veri Toplama Araçları}

\subsubsection{Sosyo-demografik bilgi formu}

Sosyo-demografik bilgi formunda; cinsiyet, yaş, eğitim durumu gibi soruların yanında katılımcıların aktif olarak araç kullanıp kullanmadıklarına ve sürücü olduğunu beyan eden katılımcılara güvenli sürüş eğitimi alıp almadıklarına yönelik sorular sorulmuştur.

\subsubsection{Trafikte değişim aşamaları anketi (DAA-T)}

Transteorik Model temel alınarak çalışmanın yazarları tarafından oluşturulan ankette trafik güvenliği açısından önemli olan emniyet kemeri kullanımı, sürüş esnasında cep telefonu kullanımı, hız sınırları dâhilinde araç kullanımı, alkollüyken araç kullanımı ve araç sürerken yemek yeme davranışlarında katılımcının kendini hangi basamakta gördügünü belirtmesi istenmiştir. Ankette her bir davranışı ölçmek için birer soru bulunmaktadır. Dolayısıyla anket 5 sorudan oluşmaktadır. Anketin yönergesinde sürücüler için "Aşağıda sürüş esnasında geçerli bazı davranışlar verilmiştir. Lütfen araç kullanırken aşağıdaki davranışlar için sizi en iyi tanımlayan seçeneği seçiniz." bulunurken henüz sürücü olmayan katılımcılara "Aşağıda sürüş esnasında geçerli bazı davranışlar verilmiştir. Eğer araç kullanıyor olsaydınız aşağıdaki davranışlar için sizi en iyi tanımlayan seçenek hangisi olurdu." yönergesi verilmiştir. Katılımcı her bir davranış için Transteorik Model'in 5 basamağını temsil eden 5 seçenekten birini seçerek kendini değerlendirmiştir.

\section{3. İşlem}

Veri toplama sürecine başlamadan önce Orta Doğu Teknik Üniversitesi (ODTÜ) İnsan Araştırmaları Etik Kurulu'ndan çalışmanın etik izni alınmıştır. Etik izin sağlandıktan sonra veri toplamak için kullanılacak olan anketler ve gönüllü katılım formu Qualtrics Survey Software isimli internet sitesine yüklenmiş ve çalışma sosyal medya aracılığı ile yayılmıştır. Çalışmanın başlangıcında katılımcılara gönüllü katılımcı formu sunulmuş; sadece gönüllü olan katılımcılar diğer anketlere devam etmişlerdir. Anketleri tamamladıktan sonra isteyen katılımcılar çalışma hakkında görüşlerini internet üzerinden araştırmacılara iletebilmişlerdir. Elde edilen veriler SPSS programı ile analiz edilmiştir.

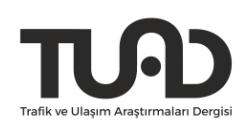




\section{Bulgular}

\subsection{Tanımlayıcı Bulgular}

Sürücü olmayan kişilerin, güvenli sürüş eğitimi almış sürücülerin ve bu eğitimi almamış sürücülerin trafik güvenliği açısından önemli 5 davranışı gerçekleştirmek ya da gerçekleştirmemek anlamında Transteorik Model'in hangi basamağında olduğu tanımlanmıştır.

Henüz sürücü olmayan grubun çoğunluğunun hız sınırları dâhilinde araç kullanımında ve sürüş esnasında cep telefonu kullanımında harekete geçme basamağında; alkollüyken araç kullanımında ve emniyet kemeri kullanımında sürdürme basamağında; sürüş esnasında yemek yemede ise hazırlık basamağında olduklarını ifade ettikleri görülmektedir. Güvenli sürüş eğitimi (GSE) almış sürücülerin yoğunlaştığı basamaklar incelendiğinde bu grubun çoğunluğunun tüm riskli davranışlarda harekete geçme basamağında olduğu görülmektedir. GSE almamış sürücülerin çoğunluğunun hız sınırları dâhilinde araç kullanımında ve sürüş esnasında cep telefonu kullanımında hazırlık basamağında; alkollüyken araç kullanımında, emniyet kemeri kullanımında ve sürüş esnasında yemek yemede harekete geçme basamağında olduklarını ifade ettikleri gözlemlenmiştir. Tablo 2'de basamakta bulunan katılımcı sayısı ve yüzdesi detaylı bir şekilde verilmektedir.

Tablo 2. Transteorik Model'in basamaklarına göre katılımcıların dăğlımları

\begin{tabular}{|c|c|c|c|c|c|c|c|}
\hline & & & $\begin{array}{c}\text { Ön } \\
\text { düşünme }\end{array}$ & Düşünme & Hazırlık & $\begin{array}{c}\text { Harekete } \\
\text { Geçme }\end{array}$ & Sürdürme \\
\hline \multirow{3}{*}{$\begin{array}{l}\text { Hız sınırları } \\
\text { dâhilinde } \\
\text { araç } \\
\text { kullanımı }\end{array}$} & \multirow{3}{*}{$\begin{array}{l}\text { Sayı } \\
(\%)\end{array}$} & $\mathrm{SD}$ & $\begin{array}{c}1 \\
(.8)\end{array}$ & $\begin{array}{c}0 \\
(0)\end{array}$ & $\begin{array}{c}35 \\
(29.2)\end{array}$ & $\begin{array}{c}63 \\
(52.5)\end{array}$ & $\begin{array}{c}21 \\
(17.5)\end{array}$ \\
\hline & & GSS & $\begin{array}{c}2 \\
(2)\end{array}$ & $\begin{array}{c}4 \\
(4)\end{array}$ & $\begin{array}{c}35 \\
(35.4)\end{array}$ & $\begin{array}{c}43 \\
(43.4)\end{array}$ & $\begin{array}{c}15 \\
(15.2)\end{array}$ \\
\hline & & $S$ & $\begin{array}{c}1 \\
(.7)\end{array}$ & $\begin{array}{c}7 \\
(5)\end{array}$ & $\begin{array}{c}73 \\
(52.1)\end{array}$ & $\begin{array}{c}51 \\
(36.4)\end{array}$ & $\begin{array}{c}8 \\
(5.7)\end{array}$ \\
\hline \multirow{3}{*}{$\begin{array}{c}\text { Alkollüyken } \\
\text { araç } \\
\text { kullanımı }\end{array}$} & \multirow{3}{*}{$\begin{array}{l}\text { Sayı } \\
(\%)\end{array}$} & SD & $\begin{array}{c}1 \\
(.8)\end{array}$ & $\begin{array}{c}0 \\
(0)\end{array}$ & $\begin{array}{c}6 \\
(5)\end{array}$ & $\begin{array}{c}45 \\
(37.5)\end{array}$ & $\begin{array}{c}68 \\
(56.7)\end{array}$ \\
\hline & & GSS & $\begin{array}{c}0 \\
(0)\end{array}$ & $\begin{array}{c}1 \\
(1)\end{array}$ & $\begin{array}{c}7 \\
(7.1)\end{array}$ & $\begin{array}{c}65 \\
(65.7)\end{array}$ & $\begin{array}{c}26 \\
(26.3)\end{array}$ \\
\hline & & $S$ & $\begin{array}{c}1 \\
(.7)\end{array}$ & $\begin{array}{c}3 \\
(2.1) \\
\end{array}$ & $\begin{array}{c}36 \\
(25.7) \\
\end{array}$ & $\begin{array}{c}85 \\
(60.7) \\
\end{array}$ & $\begin{array}{c}15 \\
(10.7)\end{array}$ \\
\hline \multirow{3}{*}{$\begin{array}{c}\text { Emniyet } \\
\text { Kemeri } \\
\text { kullanımı }\end{array}$} & \multirow{3}{*}{$\begin{array}{l}\text { Sayı } \\
(\%)\end{array}$} & SD & $\begin{array}{c}1 \\
(.8)\end{array}$ & $\begin{array}{c}4 \\
(3.3) \\
\end{array}$ & $\begin{array}{c}5 \\
(4.2) \\
\end{array}$ & $\begin{array}{c}35 \\
(29.2)\end{array}$ & $\begin{array}{c}75 \\
(62.5) \\
\end{array}$ \\
\hline & & GSS & $\begin{array}{c}1 \\
(1)\end{array}$ & $\begin{array}{c}1 \\
(1)\end{array}$ & $\begin{array}{c}8 \\
(8.1) \\
\end{array}$ & $\begin{array}{c}61 \\
(61.6) \\
\end{array}$ & $\begin{array}{c}28 \\
(28.3) \\
\end{array}$ \\
\hline & & $S$ & $\begin{array}{c}2 \\
(1.4) \\
\end{array}$ & $\begin{array}{c}0 \\
(0)\end{array}$ & $\begin{array}{c}23 \\
(16.4) \\
\end{array}$ & $\begin{array}{c}91 \\
(65) \\
\end{array}$ & $\begin{array}{c}24 \\
(17.1)\end{array}$ \\
\hline \multirow{3}{*}{$\begin{array}{c}\text { Cep } \\
\text { telefonu } \\
\text { kullanımı }\end{array}$} & \multirow{3}{*}{$\begin{array}{l}\text { Sayı } \\
(\%)\end{array}$} & SD & $\begin{array}{c}2 \\
(1.7)\end{array}$ & $\begin{array}{c}0 \\
(0)\end{array}$ & $\begin{array}{c}25 \\
(20.8)\end{array}$ & $\begin{array}{c}65 \\
(54.2) \\
\end{array}$ & $\begin{array}{c}28 \\
(23.3)\end{array}$ \\
\hline & & GSS & $\begin{array}{c}2 \\
(2)\end{array}$ & $\begin{array}{c}7 \\
(7.1)\end{array}$ & $\begin{array}{c}31 \\
(31.3)\end{array}$ & $\begin{array}{c}45 \\
(45.5)\end{array}$ & $\begin{array}{c}14 \\
(14.1)\end{array}$ \\
\hline & & $S$ & $\begin{array}{c}1 \\
(.7)\end{array}$ & $\begin{array}{c}15 \\
(10.7)\end{array}$ & $\begin{array}{c}74 \\
(52.9)\end{array}$ & $\begin{array}{c}45 \\
(32.1)\end{array}$ & $\begin{array}{c}5 \\
(3.6)\end{array}$ \\
\hline
\end{tabular}


Tablo 2. Devam

\begin{tabular}{|c|c|c|c|c|c|c|c|}
\hline & & & $\begin{array}{c}\text { Ön } \\
\text { düşünme }\end{array}$ & Düşünme & Hazırlık & $\begin{array}{c}\text { Harekete } \\
\text { Geçme }\end{array}$ & Sürdürme \\
\hline \multirow{3}{*}{$\begin{array}{l}\text { Yemek } \\
\text { yeme }\end{array}$} & \multirow{3}{*}{$\begin{array}{l}\text { Sayı } \\
(\%)\end{array}$} & SD & $\begin{array}{c}5 \\
(4.2) \\
\end{array}$ & $\begin{array}{c}2 \\
(1.7) \\
\end{array}$ & $\begin{array}{c}52 \\
(43.3) \\
\end{array}$ & $\begin{array}{c}46 \\
(38.3) \\
\end{array}$ & $\begin{array}{c}15 \\
(12.5)\end{array}$ \\
\hline & & GSS & $\begin{array}{c}3 \\
(3)\end{array}$ & $\begin{array}{c}3 \\
(3)\end{array}$ & $\begin{array}{c}23 \\
(23.2)\end{array}$ & $\begin{array}{c}57 \\
(57.6) \\
\end{array}$ & $\begin{array}{c}13 \\
(13.1)\end{array}$ \\
\hline & & $\mathrm{S}$ & $\begin{array}{c}13 \\
(9.3)\end{array}$ & $\begin{array}{c}12 \\
(8.6)\end{array}$ & $\begin{array}{c}36 \\
(25.7)\end{array}$ & $\begin{array}{c}72 \\
(51.4)\end{array}$ & $\begin{array}{c}7 \\
(5)\end{array}$ \\
\hline
\end{tabular}

Not. $S D=$ Sürücü değil, GSS = Güvenli Sürüş Eğitimi Almış Sürücü, $S=$ Güvenli Sürü̈s Eğitimi Almamış Sürücü

\subsection{Gruplar Arası Farklar}

Gelecekte araç kullanacak, GSE almış ve GSE almamış sürücülerin, araştırma kapsamında incelenen sürücü davranışlarında Transteorik Model basamakları temelinde değerlendirildiklerinde birbirlerinden farklılaşıp farklılaşmadığını araştırmak amacıyla tek yönlü bağımsız gruplar kovaryans analizleri (ANCOVA) yapılmış; cinsiyet ve yaşın olası etkileri kontrol edilmiştir. Kategorik bir değişken olan cinsiyet için yapay (dummy) kodlama kullanılmıştır. Yapılan analiz sonucunda grupların homojenliği varsayımının karşılanmadığ görülmüş ama bu varsayımın çoğunlukla ihlal edildiği (Field, 2016) gözlemlendiği için analize devam edilmiştir. Gruplar arasında anlamlı farklar gözlenen değişkenlerin yer aldığ grafik aşağıdadır (bkz. Şekil 1).

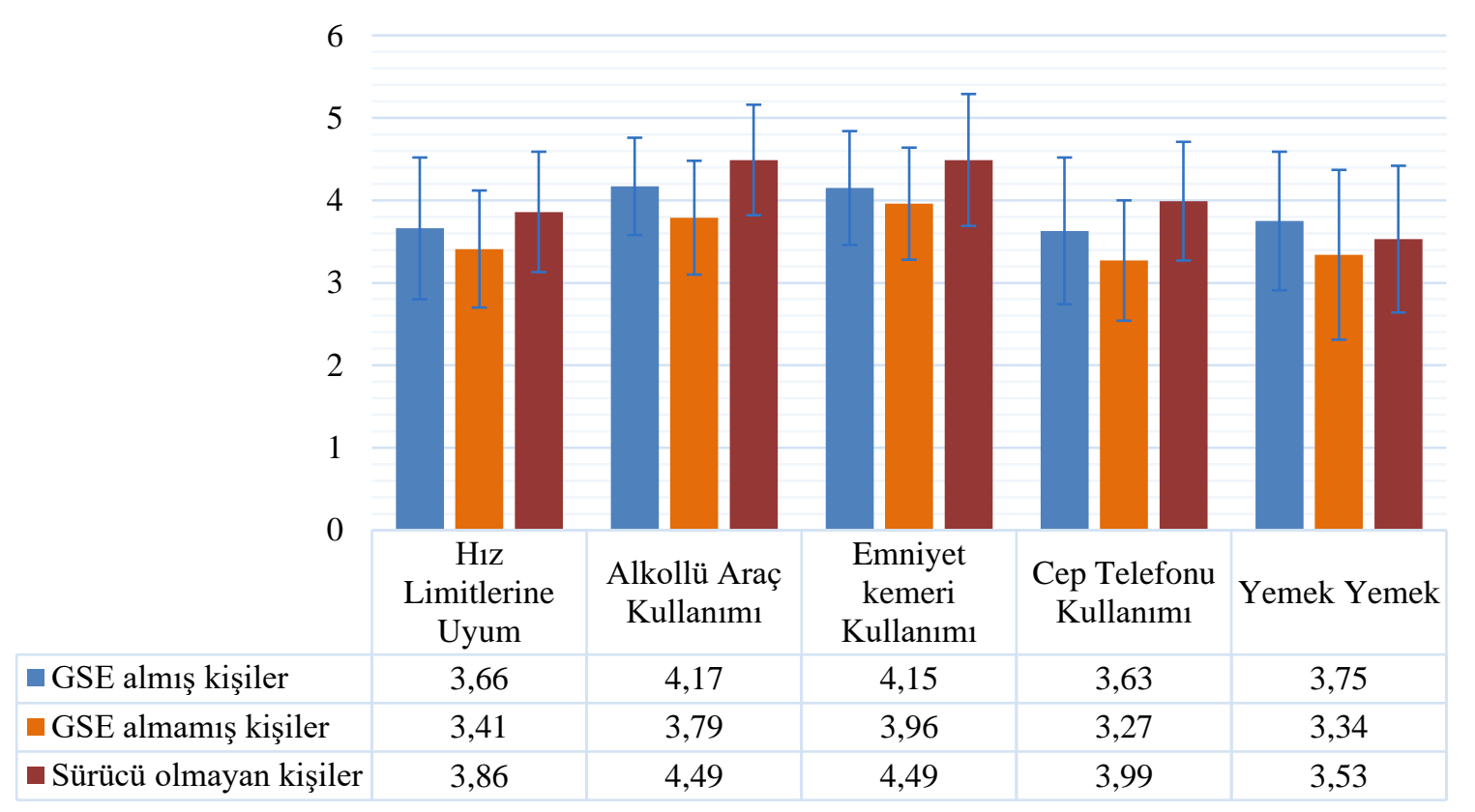

Şekil 1. Bă̆ımsız gruplar kovaryans analizleri sonuçları

Katılımcıların yaş ve cinsiyetleri kontrol edildikten sonra sürüş anlamında deneyimlerinin olup olmadığının ve eğitim alıp almadıklarının hız sınırları dâhilinde araç kullanmak anlamında Transteorik modele göre bulundukları basamağa anlamlı ana etkisi olduğu görülmüştür, $F(2,354)=12,03, p<.001$. Bonferroni çoklu karşılaştırma testi ile yapılan analizlerde GSE almamış sürücüler $(M=3.41, S D=0.71)$, sürücü olmayan gruptan $(M=$ $3.86, S D=0.73)$ ve GSE almış sürücülerden $(M=3.66, S D=0.86)$ anlamlı derecede farklı bulunmuştur (sırasıyla $p<.001$ ve $p<.05$ ). GSE almış sürücüler ile henüz sürücü olmayan grup arasında hız sınırları dâhilinde araç kullanımında kişinin bulunduğu basamakta anlamlı bir fark bulunmamıştır.

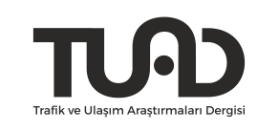


Katılımcıların yaş ve cinsiyetleri kontrol edildikten sonra sürüş anlamında deneyimlerinin olup olmadığının ve eğitim alıp almadıklarının alkollüyken araç kullanmak anlamında Transteorik modele göre bulundukları basamağa anlamlı ana etkisi olduğu görülmüştür $(F(2$, $354)=23.81, p<.001)$. Bonferroni çoklu karşılaştırma testi ile yapılan analizlerde GSE almamış sürücüler $(M=3.79, S D=0.69)$, sürücü olmayan gruptan $(M=4.49, S D=0.67)$ ve GSE almış sürücülerden $(M=4.17, S D=0.59)$ anlamlı derecede farklı bulunmuştur (Her iki grup için de $p<.001)$. GSE almış sürücüler ile henüz sürücü olmayan grup arasında alkollüyken araç kullanımında kişinin bulunduğu basamakta anlamlı bir fark bulunmamıştır.

Katılımcıların yaş ve cinsiyetleri kontrol edildikten sonra sürüş anlamında deneyimlerinin olup olmadığının ve eğitim alıp almadıklarının emniyet kemeri kullanmak anlamında Transteorik modele göre bulundukları basamağa anlamlı ana etkisi olduğu görülmüştür $(F(2$, $354)=8.96, p<.001)$. Bonferroni çoklu karşılaştırma testi ile yapılan analizlerde sürücü olmayan grubun ortalaması $(M=4.49, S D=0.80), G S E$ almamış sürücülerden $(M=3.96, S D$ $=0.68)$ anlamlı derecede farklı bulunmuştur $(p<.001)$. GSE almış sürücüler $(M=4.15, S D=$ $0.69)$ ile diğer iki grup arasında emniyet kemeri kullanımında kişinin bulunduğu basamakta anlamlı bir fark bulunmamıştır.

Katılımcıların yaş ve cinsiyetleri kontrol edildikten sonra sürüş anlamında deneyimlerinin olup olmadığının ve eğitim alıp almadıklarının sürüş esnasında cep telefonu kullanmak anlamında Transteorik modele göre bulundukları basamağa anlamlı ana etkisi olduğu görülmüş̧ür $(F(2,354)=29.10, p<.001)$. Bonferroni çoklu karşılaştırma testi ile yapılan analizlerde sürücü olmayan grubun ortalaması $(M=3.99, S D=0.72)$, GSE almış sürücülerden $(M=3.63, S D=0.89)$ ve $\mathrm{GSE}$ almamış sürücülerden $(M=3.27, S D=0.73)$ anlamlı derecede farklı bulunmuştur (Her iki grup için de $p<.001$ ). GSE almış sürücüler ile GSE almamış sürücüler arasında da sürüş esnasında cep telefonu kullanımında kişinin bulunduğu basamakta anlamlı bir fark bulunmuştur $(p<.001)$.

Katılımcıların yaş ve cinsiyetleri kontrol edildikten sonra sürüş anlamında deneyimlerinin olup olmadığının ve eğitim alıp almadıklarının araç kullanırken yemek yememek anlamında Transteorik modele göre bulundukları basamağa anlamlı ana etkisi olduğu görülmüştür $(F(2$, $354)=9.12, p<.001)$. Bonferroni çoklu karşılaştırma testi ile yapılan analizlerde GSE almamış sürücüler $(M=3.34, S D=1.03)$, sürücü olmayan gruptan $(M=3.53, S D=0.89)$ ve GSE almış sürücülerden $(M=3.75, S D=0.84)$ anlamlı derecede farklı bulunmuştur (Her ikisi için de $p<.001)$. GSE almış sürücüler ile henüz sürücü olmayan grup arasında sürüş esnasında yemek yeme davranışında kişinin bulunduğu basamakta anlamlı bir fark bulunmamıştır. Tablo 3 'de grup karşılaştırılmaları detaylı bir şekilde verilmiştir.

Tablo 3. Cinsiyet ve yaş kontrol edildikten sonra 3 grubun ortalamaları ve ANCOVA sonuçları

\begin{tabular}{|c|c|c|c|c|c|}
\hline & $\begin{array}{c}\text { Sürücü } \\
\text { olmayanlar }\end{array}$ & $\begin{array}{c}\text { GSE } \\
\text { almamıș }\end{array}$ & $\begin{array}{l}\text { GSE } \\
\text { almiș }\end{array}$ & $F$ & $\eta^{2} p$ \\
\hline H1z limitlerine uyum & $3.86^{\mathrm{a}}$ & $3.41^{\mathrm{b}}$ & $3.66^{\mathrm{a}}$ & $12.03^{* * *}$ & .06 \\
\hline $\begin{array}{l}\text { Alkollüyken araç } \\
\text { kullanımı }\end{array}$ & $4.49^{\mathrm{a}}$ & $3.79^{b}$ & $4.17^{\mathrm{a}}$ & $23.81^{* * * *}$ & .12 \\
\hline $\begin{array}{l}\text { Emniyet kemeri } \\
\text { kullanımı }\end{array}$ & $4.49^{\mathrm{a}}$ & $3.96^{\mathrm{b}}$ & $4.15^{\mathrm{ab}}$ & $14.02^{* * *}$ & .07 \\
\hline Cep telefonu kullanımı & $3.99^{\mathrm{a}}$ & $3.27^{\mathrm{b}}$ & $3.63^{\mathrm{c}}$ & $29.10^{* * *}$ & .14 \\
\hline Yemek yeme & $3.53^{\mathrm{a}}$ & $3.34^{\mathrm{b}}$ & $3.75^{\mathrm{a}}$ & $9.12^{* * *}$ & .05 \\
\hline
\end{tabular}




\section{Tartışma}

$\mathrm{Bu}$ çalışmada sürücü belgesi bulunmayan, sürücü belgesi bulunan ve sürücü belgesinin yanı sıra güvenli sürüş eğitimi (GSE) almış kişilerin riskli sürücülük davranışları Transteorik model çerçevesinde incelenmiştir. Bu amaçla, Türkiye ve dünya istatistikleri (Trafik Güvenliği Dairesi Başkanlığı, 2016; WHO, 2015) göz önünde bulundurularak, en riskli sürücülük davranışlarından beş tanesi olan hız sınırlarına uygun araç kullanmamak, alkollü araç kullanmak, emniyet kemeri kullanmamak, araç kullanırken cep telefonu kullanmak ve yemek yemek seçilmiştir.

Transteorik Model veya Değişim Basamakları Modeli, Prochaska ve DiClemente (1983) tarafindan sigarayı bırakma davranışı üzerine ortaya konmuş olmakla birlikte diğer birçok sağlıklı davranışın geliştirilmesi için de başarıyla uygulanmıştır. Bu modele göre, öndüşünme, düşünme, hazırlık, harekete geçme ve sürdürme, davranış değişimindeki beş basamağı göstermektedir. Trafik kazalarına neden olan riskli sürücü davranışlarının insanların kendileri ve diğerleri için olumsuz olduğu kabul edilerek, yukarıda bahsi geçen bu davranışlar sürücü belgesi bulunmayan, sürücü belgesi bulunan ve sürücü belgesinin yanı sıra güvenli sürücülük eğitimi almış kişiler arasında Transteorik Model çerçevesinde karşılaştırılmıştır.

Araç kullanırken hız limitlerine uymak, alkollüyken araç kullanmak ve sürüş esnasında yemek yemek davranışlarında henüz sürücü olmayan katılımcıların, GSE almamış sürücülerin ve GSE almış sürücülerin ortalamaları genellikle harekete geçme basamağına yakın yoğunlaşmış olduğu gözlemlenmektedir. Bu üç davranışta GSE almamış sürücüler henüz sürücü olmayan katılımcılara ve GSE almış sürücülere kıyasla anlamlı ölçüde Transteorik Modele göre daha alt basamaklarda yer aldıklarını yani güvensiz/sağlıksız davranışı değiştirmeye ve/ya güvenli/sağlıklı davranışı sürdürmeye daha uzak olduklarını beyan etmektedirler. Daha önce yapılmış bir çalışmada da $30 \mathrm{~km} / \mathrm{s}$ sürüş hızının sürücüler ve sürücü olmayan kişiler için aynı zihinsel temsile denk gelmediği bulunmuş, bunun nedeni henüz sürücü olmayanların bu temsile temel sağlayacak deneyimlerinin olmayışı olarak gösterilmiştir (Bordarie, 2017). 2016 yılında yapılan bir çalışma (Trafik İstatistik Bülteni, 2016) Türkiye'deki binlerce sürücünün hız limitlerinin üzerinde sürüş yapmaları nedeniyle ölümlü ve yaralanmalı kazalara sebep olduğunu ortaya koymuştur. GSE almamış sürücülerin hazırlık basamağında yoğunlaşması yani kimi zaman hız sınırlarına uyarken kimi zaman uymamaları da bu yüksek kaza sayılarını tekrar eder niteliktedir. Yıılık sürüş miktarı, hızlı sürüşten zevk alma ve hıza izin verecek araca sahip olma gibi değişkenlerin hız yapma için belirleyici etkenler olması (Yannis, Louca, Vardaki ve Kanellaidis, 2013), ehliyeti olmayan kişilerin hız sınırlarına uymakta daha yüksek eğilime sahip olmalarını açıklıyor olabilir. Diğer bir deyişle bu fark henüz sürücü koltuğuna oturmamış ve sürücü olmanın içsel ve dışsal dinamikleriyle tanışmamış olmalarından dolayı olabilir. Bunu doğrular nitelikteki bir başka çalışmada hız sınırlarına uymakla ilgili bir reklam kampanyasının sürücüler ve sürücü olmayanlar üzerine etkisini inceleyen bir araştırmada sürücüler ile sürücü olmayanların odaklandıkları noktaların farklı noktalar olduğu; sürücü olmayanların sürüşle ilgisi olmayan kısımlara daha çok odaklandığı bulunmuştur (Janssens ve De Pelsmacker, 2007). Bu nedenle belki de sürücü olmayan kişiler, hız yapmanın nedeni olarak gösterilen sebepleri değerlendirmektense kendileriyle ilgili başka bilgileri (örn; trafik harici ortamlardaki davranışları) değerlendirmeye almaktadır ve trafiğe çıktıklarında kurallara uyacakları yönünde olumlu beyanda bulunmaktadır. $\mathrm{Bu}$ olumlu yaklaşımdan vazgeçmemeleri için bulundukları harekete geçme basamağı düşünülerek trafik sistemine katılmadan önce önleyici çalışmalar yapılmalı ya da katıldıktan sonra çeşitli takip mekanizmaları ve yaptırımlar uygulanmalıdır. Bunun yanı sıra, hız limitleri dâhilinde araç kullanma konusunda GSE almış sürücülerin, GSE almamış kişilerden anlamlı bir şsekilde ayrışması önemli bir bulgudur. Eğitimlerde teorik ve uygulamalı olarak değinilen hızın etkileri, uygulamalarda sürtünme ve

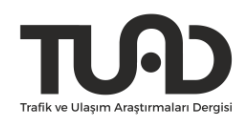


araç kontrolü bakımından geribildirimlerle de sürücüye aktarılmaktadır. Diğer iki davranış için ise spesifik teorik ve pratik eğitimler olamamakla birlikte güvenli sürüş eğitimlerinin temelini oluşturan güvenlik algısına yönelik müdahalelerin bu iki davranışta da hedefine ulaştığ1 söylenebilir. Transteorik Model'in öngördüğü üzere eğitimlerin uygun basamağa yönelik müdahaleyi içerdiği ve eğitimin sürücülerin bulunduğu basamağ düşünülmektedir; bu eğitimlerin içeriğinin ehliyet kurslarına da aktarılması geleceğin sürücülerinin üst basamakta kalmasına hatta sürdürme basamağına ilerlemelerine yol açacak müdahale çalışmalarından biri olabilir.

Sürüş esnasında sürücülerin kendi dikkatlerini dağıtacak başka şeylerle ilgilenmeleri trafik güvenliği çalışmalarında önem taşıyan bir başka riskli konudur. Araç kullanırken cep telefonuyla ilgilenmek ve/veya yemek yemek bu anlamda en sık karşılaşılan dikkat dağıtıcı aktivitelerden ikisidir (WHO, 2015; Trafik Güvenliği Dairesi Başkanlığı, 2016). Trafiğin çoğunluğunu oluşturan GSE almamış sürücülerin sürüş esnasında yemek yeme davranışında harekete geçme basamağında yoğunlaştığı gözlemlenirken, sürüş esnasında cep telefonu basamağında henüz hazırlık basamağında yoğunlaştıkları gözlemlenmektedir. Basamaklar için yoğunlaşma iki davranış göz önünde bulundurulduğunda ehliyeti bulunmayan kişiler için tam tersi şekildedir. Dikkat bozucu davranışların sürücülere güvenlik açısından ne oranda riskli geldiğini inceleyen bir araştırmada, sürüş esnasında cep telefonu kullanmanın en tehlikeli davranış olarak ortaya çıktığı; yemek yemenin ise riskli bir davranış olarak algılanmadığı ortaya koyulmuştur (White, Eiser ve Harris, 2004). Bu bulgu dâhilinde sonuçlar değerlendirildiğinde daha riskli algılanan bir davranışta sürücülerin daha alt bir basmakta bulunmaları ilginçtir; ancak aynı çalışmada riskli olan bu davranışı katılımcıların yarısından fazlasının yaptıklarını beyan ettikleri ve kendileri haricindeki kişilerin bu davranışı yapmalarının kazaya neden olabileceğini düşünürken kendilerinin telefon kullanmalarının böyle bir şeye yol açmayacakları yanlılığına sahip oldukları da bulunmuştur (White, Eiser ve Harris, 2004). Bu yanlılık mevcut çalışmamızın sonuçlarını da açıklar nitelikte olabilir. Cep telefonu kullanma davranışında sürücü adaylarının GSE almış sürücülere göre de anlamlı ölçüde daha üst basamaklarda yer aldığı görülmektedir. Dolayısıyla, eğitim almış sürücüler, eğitim almamış sürücüler ve sürücü adayları her ne kadar üst basamaklarda yer alıp araç kullanırken cep telefonuyla ilgilenmekten ve yemek yemekten kaçınma eğiliminde olsalar da, telefonu kullanmamayı ve yemek yememeyi alışkanlık haline getirmeleri için çeşitli müdahaleler yapılması gerektiği ortadadır. Örneğin; ön-düşünme basamağında olan kişiler için farkındalık arttırma yöntemi ile sürücülük eğitimlerinde sürücü adaylarına simülatörde cep telefonuyla sürüş gerçekleştirmesi istenip o esnadaki dikkat ettikleri ve kaçırdıkları ayrıntıların geribildirimi sağlanırken, daha ileri başmaklarda olan adaylar için karşıt koşullama yöntemi kullanılıp cep telefonu ile sürüş esnasında telefon eline alındığı an rahatsız edici bir ses verilerek telefondan alınan zevk yerine uyaranın rahatsızlıkla eşleştirilmesi sağlanabilir. $\mathrm{Bu}$ örneklerin sadece bir örnek olduğu ve derinlemesine düşünülüp araştırılmadan hayata geçirilemeyeceği ortadadır.

Emniyet kemeri kullanımına dair ehliyet sahibi olmayan yani henüz araç kullanmayan kişilerin GSE almamış sürücü grubuna kıyasla daha güvenli seviyede davranış sergileyeceklerine dair beyanları çalışmanın diğer değişkenlerinin sonuçlarıyla benzer yönde olup, GSE almış sürücülerin diğer gruplardan farklılaşmamaları beklenmedik bir bulgu olmuştur. Tüm katılımcılar göz önüne alındığında emniyet kemeri kullanımında katılımcıların kendilerini harekete geçme ve sürdürme basamaklarında beyan ettikleri görülmektedir. Emniyet kemeri kullanımının önemi Türkiye'de uzun yıllardır birçok medya organı aracılığıyla vurgulandığı gibi, çeşitli kamera ve denetim mekanizmasıyla da takip edilmektedir. Bunların yanı sıra, araçlarda emniyet kemeri kullanımını artırmak için geliştirilen uyarıcı sistemler de sürücüleri emniyet kemeri kullanmaya yöneltmektedir; bu

\section{TQD}


yüksek oranın bu kampanyalardan kaynaklanıyor olabileceği düşünülse de bu sonuçların beyana dair olduğu ve gerçek davranışı yansıtmıyor olabileceği unutulmamalıdır. Özkan ve arkadaşları (2012), yaptıkları çalışmada sürücülerin emniyet kemeri kullanıp kullanmadıklarına dair beyana dayalı sonuçlarıyla, araştırmacıların aynı sürücülere dair gözleme dayalı ölçümlerini karşılaştırmışlar; beyan edilen emniyet kemeri kullanım oranıyla gözlem oranları arasında anlamlı bir fark bulmuşlardır. Kişilerin beyanlarındaki olumlu yöndeki yoğunluğun, kişisel beyanlardaki iyimserlikten kaynaklanıyor olabileceği düşünüldüğü gibi seçilen örneklemden de kaynaklanıyor olabileceği ya da yıllar içinde güvenliğe yönelik tutumun olumlu yönde değişmiş olabileceği de düşünülmüştür.

Sonuçlar genel olarak değerlendirildiğinde, 5 riskli davranışta da sürücü olmayanlar kendilerinin ileriki sürücülüklerinde şimdiki eğitim almamış sürücüler kıyasla daha güvenli davranışlar sergileyeceklerini beyan etmişlerdir. Daha önce yapılan bir çalışmada da aynı yönde sonuçlar bulunmuş henüz sürücü olmayan katılımcıların yüzde kırkına yakının kendilerini ortalama bir sürücüden daha iyi değerlendirdikleri ortaya konmuştur (Mynttinen ve ark., 2009). Emniyet kemeri kullanımı davranışı hariç diğer 4 riskli davranışta da güvenli sürüş eğitimi almış sürücüler eğitimi almamış sürücülerden anlamlı ölçüde daha fazla güvenli davranış sergilediklerini beyan etmişler; ama cep telefonu kullanımı hariç 4 riskli davranışta henüz sürücü olmayan grup ile eğitim almış sürücü grubu arasında anlamlı bir fark bulunamamıştır. Yapılan bir çalışmada sürücü eğitimine ek olarak güvenli sürüş eğitimi verilmiş grup ve ek eğitimi almamış olan kontrol grubu karşılaştırılmış ve iki grubun da ilk ölçüme göre sürüşünde gelişmeler olduğu gözlemlenmiş ama iki grup arasında anlamlı fark bulunamamıştır (Harré ve Field, 1998). Yaşlı sürücülere teorik ve uygulamalı güvenli sürüş eğitimi verilerek öncesi ve sonrası ölçüm yapılan bir çalışmada teorik eğitimin bilgi anlamında önemli bir fark yarattığ 1 ; uygulama kısmının ise aynı derecede etkili olmadığ bulunmuştur (Porter ve ark., 2008). Bu sonuçlar doğrultusunda üç grubun birbirinden farklılaşmadığı davranışlar anlamlandırılabilir. Literatürdeki bulgular ile birlikte değerlendirildiğinde kişilerin tutumunun yanı sıra tutumun davranışa dönüşmesinde birçok çevresel faktör ve uygulama (örn; cezai yaptırımlar, davranışlarla ilgili atıflar gibi) etken olabilmektedir. Cezai yaptırımların güvensiz davranış sergileyen sürücüler için geribildirim niteliğine sahip olduğu ortada olup, bu yaptırımlara maruz kalan sürücülerin kendileriyle ilgili gerçekliğe daha yakın bir değerlendirmeye sahip olabilecekleri düşünülebilir. Henüz sürüş deneyimi olmayan bireyler bu etkenleri hiç deneyimlememiş olduğundan diğer gruplardan daha üst basamaklarda kendilerini ifade etmişken, güvenli sürüş eğitimi almış sürücülerin eğitimdeki bilgiler ile kendilerini bazı basamaklarda daha üst olarak ifade etmiş olması grupların farklılıklarının nedenleri arasında görülebilir. Güvenli sürüş eğitimi öncesi ve sonrası ölçüm alınan beş haftalık bir çalışmada güvenli sürüş eğitiminin kişinin kontrol odağını değiştirdiğini, dışsal nedenlere yaptıkları atıfları azaltırken içsel atıflarını attırdığı bu değişiminde güvenli sürüşle ilgili davranışları arttırdığı bulunmuştur. Genel olarak kişilerin sürüş becerileri ve güvenlikle ilgili davranışları konusunda kendilerini değerlendirmede iyimser olduğu da ortaya konmuş bulgulardan biridir. Bu iyimserliği etkileyen önemli faktörlerden birinin sürüş deneyimleri olduğu da ifade edilmiştir (Svenson, Fischhoff, ve MacGregor, 1985). Bundan dolayı henüz sürüş deneyimi olmayan katılımcıların kendilerini daha iyimser değerlendirmiş olması; sürüş eğitimi almış sürücülerin eğitimler vasıtasıyla aldıkları geri bildirimler ile kendilerini değerlendirmelerinin etkilenmiş olması da muhtemeldir.

Bu çalışma kapsamında incelenen olumsuz sürücü davranışlarının Transteorik Model'de yer alan basamaklar kapsamında incelenmesi, çalışmaya katılan sürücülerin ve sürücü adaylarının genel olarak bu olumsuz davranışlardan kaçınmak eğiliminde olduklarını göstermektedir. Khadem-Rezaiyan ve arkadaşları (2017) tarafından İran'da gerçekleştirilen çalışmada

\section{TQD}


katılımcıların cep telefonu ve emniyet kemeri kullanımında ön düşünme basamağında yer almaları, Türkiye örnekleminde ise katılımcıların bu iki basamakta sırasıyla harekete geçme ve hazırlık basamaklarında yer almaları Türkiye'deki yol kullanıcıları ve trafik ortamı için umut vericidir. Elbette, kişilerin beyanları gerçek hayattaki davranışlarına kıyasla daha olumlu ve güvenli noktada olmaktadır; fakat değişimin kişinin içinden başladığı ve içsel süreçlerin ardından davranışlarına yansıdığı düşünüldüğünde, elde edilen bulgular 1şığında sürücülerin ve sürücü adaylarının edindikleri olumlu davranışları sürdürmelerini sağlayacak faaliyetler gerçekleştirilebilir.

Çalışmanın kısıtlılıkları iki kategoride sunulabilir. İlk olarak, yapılan çalışma beyana dayalı olduğu için kişiler gerçek hayatta sergiledikleri sürücülük davranışlardan daha olumlu noktalarda kendilerini sunmuş olabilirler. Yine de, çalışmaya katılan kişilerin özellikleri yakından incelendiğinde, katılımcıların büyük oranda iyi eğitim seviyesine sahip olduğu ve üniversite öğrencileri kadar çalışanlardan da oluştuğu görülmektedir. Dolayısıyla, çalışmada yer alan örneklemin, Türkiye'deki genel öğrenim seviyesinden yukarıda olduğu ve güvenlik konusunda bilgiye ve eğitime sahip olduğu düşünülebilir. İkinci olarak, katılımcı sayısı ve temsiliyet gücü çalışmaya dair bir kısıtlılık olarak görülebilir. Her ne kadar meslek durumları ve eğitim özellikleri açısından Türkiye popülasyonunu yansıtan çeşitlilikte bir örneklem grubu oluşturulması hedeflenmiş olsa da daha sınırlı çeşitlilikte kişiye ulaşılması çalışmanın diğer bir kısıtlılı̆̆ıdır.

Yukarıda bahsedilen kısıtlılıklara rağmen bu çalışma literatüre değerli katkılar sağlamaktadır. Transteorik Model kullanılarak, trafikte sıkça rastlanan olumsuz davranışların ehliyet sahibi olmayan kişiler, ehliyet sahibi sürücüler ve güvenli sürüş eğitimi almış sürücüler dâhil edilerek incelenmesi ilk kez gerçekleştirilmiştir. Bulunan bulgular dâhilinde güvenli sürüş eğitimleri yeniden gözden geçirilebilir, eğitime katılan kişilerin basamakları değerlendirilip Transteorik Model'in önerdiği müdahaleleri içeren eğitimler yapılandırılabilir. Bunun yanı sıra zaten güvenlik anlamında kendini üst basamaklarda gören sürücü adayları için sürücü kurslarının tekrar yapılandırılması devlet kademelerince planlanabilir; harekete geçme ve sürdürme basamaklarında önerilen edimsel yöntem, yardım ilişkisi, karşıt koşullanma, uyaran kontrolü gibi müdahaleler eğitimlere dâhil edilebilir. Bu noktada unutulmaması gereken Transteorik Model'in hedef aldığı terapiye gelmiş (çoğunlukla kendi motivasyonuyla) kişileri zaten rahatsız oldukları davranıştan mutlu olacakları davranışa değiştirmeye çalışılan müdahalelerdense, kişileri hâlihazırda zevk aldıkları ve rahatsız olmadıkları davranışları değiştirmek için normal koşullama süreçlerinin aksine bir koşullama süreci gerçekleştirilecek olduğu, kişinin zevk aldığı bir eylemi zevk almadığı bir eyleme dönüştürmeye çalışıldığıdır. Bundan dolayı gelecek çalışmaların basamaklara özgü müdahalelerin neler olabileceğini dikkatle araştırmalarının trafik güvenliğini arttırmak açısından önemli olduğu düşünülmektedir. Son olarak, bu çalışma sonucunda edinilen bulgular, güvenli sürücülük davranışlarının geliştirilmesi ve sürdürülmesi açısından önem taşımaktadır. $\mathrm{Bu}$ çalışma sayesinde sürücülerin ve sürücü adaylarının kendilerini belirtilen davranışlarda hangi seviyede buldukları tespit edilmiş ve güvenli sürücülük için gidilmesi gereken yönde atılabilecek adımların belirlenmesi için bir zemin oluşturulmuştur. 


\section{Kaynakça}

Asbridge, M., Brubacher, J. R. ve Chan, H. (2012). Cell phone use and traffic crash risk: A culpability analysis. International Journal of Epidemiology, 42(1), 259-267.

Asgarabad, A. A., Tahami, A. N. ve Khanjani, N. (2012). Exposure to hand-held mobile phone use while driving among Iranian passenger car drivers: An observational study. Journal of Injury and Violence Research, 4(2), 96-97.

Beck, K. H., Yan, F. ve Wang, M. Q. (2007). Cell phone users, reported crash risk, unsafe driving behaviors and dispositions: A survey of motorists in Maryland. Journal of Safety Research, 38(6), 683-688.

Bener, A., Crundall, D., Özkan, T. ve Lajunen, T. (2010). Mobile phone use while driving: A major public health problem in an Arabian society, State of Qatar-mobile phone use and the risk of motor vehicle crashes. Journal of Public Health, 18(2), 123-129.

Bener, A., Lajunen, T., Özkan, T. ve Haigney, D. (2006). The effect of mobile phone use on driving style and driving skills. International Journal of Crashworthiness, 11(5), 459465 .

Bordarie, J. (2017). Public policy of urban mobility: Impact of the history and practices on young drivers' social representation of $30 \mathrm{~km} / \mathrm{hr}$. Journal of Nonprofit \& Public Sector Marketing, 29(2), 211-234. doi:10.1080/10495142.2017.1326346

Defansif Sürüş Eğitimi. (n.d.). Nisan 2018'de http:/hed.com.tr/Egitim/Defansif-SurusEgitimi/83 adresinden alınd.

Demirkol, İ. C., Tosun, A. P. D. H. ve Yüksel, Y. (2015). Tehlikeli araç kullanma: Kamuda çalışan şoförlerin emniyet kemeri kullanımı. Anadolu Üniversitesi Sosyal Bilimler Dergisi, 15(2), 139-152.

DiClemente, C. C., Prochaska, J. O., Fairhurst, S. K., Velicer, W. F., Velasquez, M. M. ve Rossi, J. S. (1991). The process of smoking cessation: an analysis of precontemplation, contemplation, and preparation stages of change. Journal of Consulting and Clinical Psychology, 59(2), 295.

Evans, L. (1986). The effectiveness of safety belts in preventing fatalities. Accident Analysis \& Prevention, 18(3), 229-241.

Evans, L. ve Frick, M. C. (1986). Safety belt effectiveness in preventing driver fatalities versus a number of vehicular, accident, roadway, and environmental factors. Journal of Safety Research, 17(4), 143-154.

Field, A. (2016). Discovering statistics using IBM SPSS statistics. Los Angeles: Sage.

Harré, N. ve Field, J. (1998). Safe driving education programs at school: lessons from New Zealand. Australian and New Zealand journal of public health, 22(4), 447-450.

Huang, J. L. ve Ford, J. K. (2012). Driving locus of control and driving behaviors: Inducing change through driver training. Transportation Research Part F: Traffic Psychology and Behaviour, 15(3), 358-368.

Irwin, C., Monement, S. ve Desbrow, B. (2015). The influence of drinking, texting, and eating on simulated driving performance. Traffic Injury Prevention, 16(2), 116-123.

\section{TQD}


Isler, R. B., Starkey, N. J. ve Sheppard, P. (2011). Effects of higher-order driving skill training on young, inexperienced drivers' on-road driving performance. Accident Analysis and Prevention, 43, 1818-1827.

Janssens, W. ve De Pelsmacker, P. (2007). Fear appeal in traffic safety advertising: The moderating role of medium context, trait anxiety, and differences between drivers and non-drivers. Psychologica Belgica, 47(3), 173-193. doi:10.5334/pb-47-3-173

Karayolu Trafik Kaza İstatistikleri, 2015 (2016). Ankara: Türkiye İstatistik Kurumu Trafik Istatistik Bülteni (2016).

Khadem-Rezaiyan, M., Moallem, S. R. ve Vakili, V. (2017). High-risk behaviors while driving: A population-based study from Iran. Traffic Injury Prevention, 18(3), 257261.

Kowalski, K., Jeznach, A. ve Tuokko, H. A. (2014). Stages of driving behavior change within the transtheoretical model (TM). Journal of Safety Research, 50, 17-25.

Laude, J. R. ve Fillmore, M. T. (2015). Simulated driving performance under alcohol: effects on driver-risk versus driver-skill. Drug and Alcohol Dependence, 154, 271-277.

Mynttinen, S., Sundström, A., Vissers, J., Koivukoski, M., Hakuli, K. ve Keskinen, E. (2009). Self-assessed driver competence among novice drivers - a comparison of driving test candidate assessments and examiner assessments in a Dutch and Finnish sample. Journal of Safety Research, 40, 301-309. doi:10.1016/j.jsr.2009.04.006

Nangana, L. S., Monga, B., Ngatu, N. R., Mbelambela, E. P., Mbutshu, L. H. ve Malonga, K. F. (2016). Frequency, causes and human impact of motor vehicle-related road traffic accident (RTA) in Lubumbashi, Democratic Republic of Congo. Environmental Health and Preventive Medicine, 21(5), 350-355.

Özkan, T., Puvanachandra, P., Lajunen, T., Hoe, C. ve Hyder, A. (2012). The validity of selfreported seatbelt use in a country where levels of use are low. Accident Analysis and Prevention, 47, 75-77.

Parks V., Leister C., Patat A., Troy S., Vermeeren A., Volkerts E. R. ve Verster J.C. (2002) Effect of ethanol at a blood alcohol concentration of $0.4 \mathrm{~g} / \mathrm{l}$ on actual driving and memory. European Neuropsychopharmacology, 12(3), 432-433

Porter, M., Bedard, M., Weaver, B., Porter, M. M., Marshall, S., Molnar, F. ... ve MillerPolgar, J. (2008). The Combination of Two Training Approaches to Improve Older Adults' Driving Safety. Traffic Injury Prevention, 9(1), 70-76.

Prochaska, J. O., DiClemente, C. C. ve Norcross, J. C. (1992). In search of how people change: Applications to addictive behaviors. American Psychologist, 47(9), 1102.

Prochaska, J. ve DiClemente, C. (1983) Stages and processes of self-change in smoking: Toward an integrative model of change. Journal of Consulting and Clinical Psychology, 5, 390-395.

Rumar, K. (1985). The role of perceptual and cognitive filters in observed behavior. In Human Behavior and Traffic Safety (pp. 151-170). Springer, Boston, MA.

Sinelnikov, S. ve Wells, B. M. (2017). Distracted driving on the job: Application of a modified stages of change model. Safety Science, 94, 161-170.

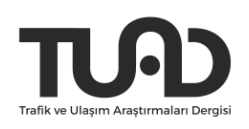


Svenson, O., Fischhoff, B. ve MacGregor, D. (1985). Perceived driving safety and seatbelt usage. Accident Analysis \& Prevention, 17(2), 119-133.

Trafik Güvenliği Dairesi Başkanlığı (2016). Trafik kazaları özeti, 2015. http://www.kgm.gov.tr/SiteCollectionDocuments/KGMdocuments/Trafik/TrafikKazal ariOzeti2015.pdf adresinden alınd1.

Tuokko, H. A., McGee, P. D. ve Rhodes, R. E. (2006). Decisional balance and readiness to change driving behavior in older adults: A pilot study. Physical \& Occupational Therapy in Geriatrics, 24(3), 1-12.

Türkiye İstatistik Kurumu (2017). Karayolu trafik kaza istatistikleri, 2016. http://www.tuik.gov.tr/PreHaberBultenleri.do?id=24606_adresinden alınd1.

White, M. P., Eiser, J. R., \& Harris, P. R. (2004). Risk perceptions of mobile phone use while driving. Risk Analysis: An International Journal, 24(2), 323-334.

World Health Organization (2013). Global status report on road safety 2013. www.who.int/vio lence_injury_prevention/road_safety_status/2013/en/ adresinden alınd1.

World Health Organization (2015). Global status report on road safety. http://www.who.int/violence_injury_prevention/road_safety_status/2015/en/ adresinden alındi.

Yannis, G., Louca, G., Vardaki, S. ve Kanellaidis, G. (2013). Why do drivers exceed speed limits. European Transport Research Review, 5(3), 165-177.

Young, M. S., Mahfoud, J. M., Walker, G. H., Jenkins, D. P. ve Stanton, N. A. (2008). Crash dieting: The effects of eating and drinking on driving performance. Accident Analysis and Prevention, 40(1), 142-148.

Zador, P. L., Krawchuk, S. A. ve Voas, R. B. (2000). Alcohol-related relative risk of driver fatalities and driver involvement in fatal crashes in relation to driver age and gender: an update using 1996 data. Journal of Studies on Alcohol, 61(3), 387-395. 